Interfaces

\title{
Strategies of Engagement in Using Life: A Multimodal Novel
}

Marie Thérèse Abdelmessih

\section{(2) OpenEdition}

1 Journals

\section{Electronic version}

URL: http://journals.openedition.org/interfaces/314

DOI: 10.4000/interfaces.314

ISSN: 2647-6754

\section{Publisher:}

Université de Bourgogne, Université de Paris, College of the Holy Cross

\section{Printed version}

Date of publication: 1 January 2017

Number of pages: 105-126

ISSN: $1164-6225$

\section{Electronic reference}

Marie Thérèse Abdelmessih, "Strategies of Engagement in Using Life: A Multimodal Novel", Interfaces [Online], 38 | 2017, Online since 13 June 2018, connection on 07 January 2021. URL: http:// journals.openedition.org/interfaces/314 ; DOI: https://doi.org/10.4000/interfaces.314

Les contenus de la revue Interfaces sont mis à disposition selon les termes de la Licence Creative Commons Attribution 4.0 International. 


\title{
"STRATEGIES OF ENGAGEMENT IN USING LIFE: A MULTIMODAL NOVEL"
}

\author{
Marie Thérèse Abdelmessih
}

Multimodality is not new to Egyptian culture whose ancient sign system was the hieroglyph (Lambeens \& Pint 240); correspondingly, ancient Egyptian two dimensional mural art was at times sequential, illustrated by hieroglyphic inscriptions. Moreover, a bas-relief dating to the Old Kingdom circa 2,000 BCE at Cairo Museum may be considered as the earliest pictorial cartoon, according to Afaf L. Margot. It bears political insinuations by depicting a conflicting relationship between the keeper and the sacred baboons in his charge (Margot 3). Later, Coptic and medieval Arabic manuscripts combined text and image (Coptic Museum). In modern times, Egyptian cartoons evolved in the second half of the nineteenth century with the founding of newspapers in 1870 . Their political humor was strongly connected to the growing antagonism against rulers (Margot 2).

Children's comics in Arabic flourished in Egypt as early as 1923 with Al-Awlad (Children), an eight-pages-long black and white newspaper, to be followed by Katkot (Chick) with serialized comic strips that have developed, ever since (Nadim Damluji 2016). The emergence of the first graphic novel by Magdy El Shafee met great obstacles for being considered by the authorities as "infringing upon public decency." It was banned under article 178 of the Egyptian penal code criminalizing such publications. Author and publisher were put to trial and had to pay a EGP 5000 fine. It was translated into English by Chris Rossetti (2012), and later reappeared in new Arabic editions. Censorship was growing apace during the Mubarak era, and graphic novels employed text and image to flout conventions by exposing the authorities despite the censored environment.

Graphic novels have gained popularity with the 2011 uprising in Egypt. More graphic novels have appeared since, such as Ahmad Nādī, Ganzeer, and Donia Maher's The Apartment at Bab El Louk (2014), winner of a Mahmoud Kahil Award. Bab El Louk is a Cairo district close to Tahrir Square where the Egyptian uprising took place. During the uprising, Tahrir Square turned into a "carnivalesque" performance stage intermediating aural, verbal, visual, and digital, blending media and performance, most of which had political insinuations. In Mikhail Bakhtin's terms this would be considered as "carnival" upturning social hierarchies. Tahrir Square became more of a mülid (folk fair) location, where performances became similar to the Bakhtinian marketplace, combining "loud cursing" 
and "organized show... imbued with the same atmosphere of freedom, frankness, and familiarity" (Bakhtin 1984a 154), thus balancing social differences.

The carnivalesque blending of media and performance, the pairing of (temporal) language and (spatial) image brings us back to Bakhtin's theory which examines the utterance within the genre; this has been related by some critics to the combination of media. Gunther Kress has argued for a semiotic dimension of genre systems as combining varied activities within a medium. He starts off by proposing language as a multimodal medium (Kress 185), and all texts as multimodal (Kress 187). This multimodal approach to all texts or forms of communication shows that different modes have various potentials and limitations, and are articulated in specific ways in different cultures.

In a similar argument, Lars Ellestrom propounds that all "“texts' and 'systems' overlap," being parts of material, sensorial, spatiotemporal and semiotic aspects," which he calls "the four "modalities' of media." Subsequently, "all forms of art, media, languages, communication and messages have some characteristics in common," allowing them to merge without dissolving (Ellestrom 10). Mark Evan Nelson and Glynda Hull have noted that Bakhtin's theory on the multimodal "chronotopes," the time-space conjunctions (Bakhtin 1981), may be considered as precursors to the interpretation of multimodality merging multifarious potentials in media. They have concluded that synthesizing several theories in a study within this scope enables a better understanding of a multimodal novel ( Nelson and Hull 416-417). Multimodality has challenged the borders separating media and has opened new forms of cultural practices and analysis that cross borders. It has promoted new strategies for collective engagement in a mediated world, creating a space for cosmopolitan repercussions.

Departing from traditional trends, experimental fiction proliferates in a cultural context where several forms of sign systems and media overlap. The carnivalesque environment referred to earlier that evolved with the Egyptian uprising has brought together creators from different social and cultural communities. Ahmed Naji's (1985) and Ayman Al Zorkany's (later Zorkany, 1982) Istikhdām al-Hayãt (2014, Using Life) is a multimodal novel challenging borderlines dividing classical and contemporary verbal narratives, comic strips, popular music, and film-making. It moves freely between the classical and the popular, as well as between world and local cultures (later referred to as $U L$ ). The popular has acquired global dimensions with the spread of information technologies, science fiction, and cyberpunk sub-genres, even among subcultural groups living at the margins. Verbal and visual overlap, enticing the reader to meander visual, verbal and musical rapport, communicating thematic connections on multiple levels simultaneously. Indeed, as Ellstrom argues, "intermediality is a precondition for all mediality" (Ellestrom 4). 
By transgressing boundaries, verbal narrative and visual text contest plot-line consistency, as well as sequential chronology in graphics, which problematizes a critical reading of the novel within a single theoretical methodology. Any critical approach has to be shaped with relevance to the experimental nature of the creative work within its cultural context. Subsequently, I will draw from several critics that range, among others, from Mikhail Bakhtin, to Thierry Groensteen, Gunther Kress and Pascal Lefévere.

\section{Naji and Zorkany: Using Life}

Naji writes and Zorkany draws. Both are experimenting with mainstream novels and comics conventions, subverting the role of the Western superhero as well as the popular Egyptian arch-villain to articulate a futuristically fantasized estranged world. The objective of this paper is to explore strategies of engagement in Using Life, a multimodal narrative, combining fiction, non-fiction, graphics and lyrics. It will trace modes of going beyond standardized formal conventions, breaking away with habitual reading protocols of classical Arabic and mainstream Egyptian fiction to create a culture of dissent. Besides the informal practice in the verbal text, of blurring boundaries among various language registers in Egyptian everyday spoken language, it merges professional and amateur writing. Correspondingly, Zorkany's comic strips break with the artistic hierarchy set by the College of Fine Arts since its establishment in Cairo in 1908. Unlike the aestheticism of Fine Arts, comic strips hold an oppositional potential interrogating habitual modes of viewing. Furthermore, Zorkany drifted away from the drawing styles commonly used in Egyptian comic artists. His comics have a wider range of drawing/shading style, and panel composition.

Naji and Zorkany have closely collaborated to synthesize verbal and visual; they have welcomed readers' critical interaction, as acknowledged at the end of their book. In fact, the visual and verbal narrative strategies used, subvert the expectations of readers habituated to mainstream fiction, and graphic novels pandering to traditional tastes. They had to face the challenge of appealing to a wider and more varied audience, a multiplicity of cultural sources, and a wider range of artistic styles, ranging from cartoons, illustrations, and graffiti to commercial ads. The far reaching economic and social changes in Egypt as a consequence of globalization policies have formed a pluricultural society. This has unsettled mainstream culture and valued principles of all cultural groups. Verbal language has been affected mostly, and the visual took precedence with the spread of communication technologies. Subsequently, this has introduced new potentials for engagement with the world. 
A society that is constantly disoriented as a result of rapid changes effected by unknown sources is in constant need to relate. Moreover, the proliferation of the graphic novel as a multimodal form came in response to an urge to engage with the world through an immersive form. According to Kress, multimodality brings to our notice that perception is the result of the human body's engagement with the world through the senses. The fact that the senses coordinate together "guarantees the multimodality of our semiotic world" (Kress 184). For Pascal Lefévre, the sensual is experienced through form: "The first and foremost dynamic process of form is engaging the feelings of the reader" (Lefévre 5). The fact that the body provides the means of engagement with the material world, would relate multimodality to "the issue of subjectivity" (Kress 187), and ways of its engagement with the world. Multimodality may be thought of as an epistemological tool invoking the reader's interaction in order to rethink complex local global relations ensuing from the clash between global technological politics and parochialism in an uneven world. Today's reader is a global and local citizen located at the crossroads of cultural encounters, and contemporary writers worldwide have become aware of limitations inflicted by traditional artistic forms, as well as the difficulty in relating to a single national culture. Subsequently, multimodal creative works worldwide are hardly confined to one literary or artistic tradition. Such is the case with Using Life (2014; later UL), the work under study.

The novel's title, Using Life is an appropriation from the Roman poet and philosopher Titus Lucretius Carus's (c.99 CE-c.55 CE) poem, The Nature of Things: De Rerum Natura, which is based on Epicurean philosophy. An epigraph appropriated from Lucretius is quoted in the book's front-matter pages. The epigraph quoted in Arabic translates as follows: "Birth-giving reccurs on and on; life is not given for possession but for use" ( $U L$ 5). Naji's appropriation of an ancient western classic, his merging of the local with the global, his mix of establishment with popular cultural products, and placing events in a contemporary setting endow the novel with a cosmopolitan context. The narrative events take place in cosmopolitan Cairo, configured as an unreal/real City that may represent the monetizing hurly-burly of any metropolitan city. However, the narrative subverts the call for "using life," advocated by the book's title and the Lucretian epigraph by failing to affirm them. Unlike Lucretius's poem resplendent with natural imagery and sensuality promoting intellectual pleasure, the preponderant imagery in the novel is that of a yellowish desert, sometimes orange at its best, and that of a ravaged Cairo razed to the ground. 


\section{Appropriation as subversion}

As opposed to Lucretius's birth-giving nature, the events in the novel are stirred into action by a geographical catastrophe - a devastating desert tsunami inundating Cairo under a sand avalanche, along with a deadly massive earthquake causing streets and bridges to break down, land and ground to fall down and eventually, the collapse of the pyramids; Cairo is immersed in an overwhelming agony, a bewildering pathos. The language used to describe the tsunami appropriates that of the sacred texts, with phrases like "the wrath of god" and "Heavenly damnation," relating the overwhelming situation. Again, as in The Nature of Things, the element of chance - not divine intervention - is persistent, however, paradoxically, disabling the natural use of life.

\section{Disruptions: graphic and verbal}

The presence of death in life initiated in the verbal narrative, is visually configured by a graphic design in a two-page spread with a caption appropriated from the Natasha Atlas's lyric: "You're looking for paradise, while it surrounds you" (UL 12-13). Instead of an enchanting landscape illustrating the lyric's words, the graphic drawing is of a devastated bathroom. The drawing is in shades of grey and a predominantly obscure background. Streaks of light emanating from an unknown source make visible a toilet, a tub overflowing with a bloody liquid, sharp-cutting metal tools, and female underwear negligently thrown. ${ }^{1 *}$ The prevalence of decay is heightened by the use of stark chiaroscuro. The contrast of light and deep shades adds a claustrophobic noir atmosphere. The image may be viewed from another perspective as, to use Thierry Groensteen's terms, a "tabular surface," for spatial relationships, (Groensteen 13). The contrast between the white typography placed at the top of the drawing and the black background heightens the contradictory relationship between the meaning of the lyric and the visual affect. The sharp contrasts in shades, along with the deformed non-representational objects, function as tools to immerse the viewer in apprehensive emotions (Fig. 1).

Subsequently, the graphic spread cannot be viewed as a comic strip; the textual code emerging from the obscure space is deliberately disrupted by the gloomy environment evoked by the grey shades and sharp contrasts. The visual function of the typography becomes more active than the textual code

\footnotetext{
"Editor's note: the graphic's allusion seems to be to David's "The Death of Marat." A reference to the assassination of Marat, a Jacobite betrayed by a fellow revolutionary Charlotte Corday belonging to a different faction - the Girondins. It can also be to all too commonplace urban violence and suicides.
} 


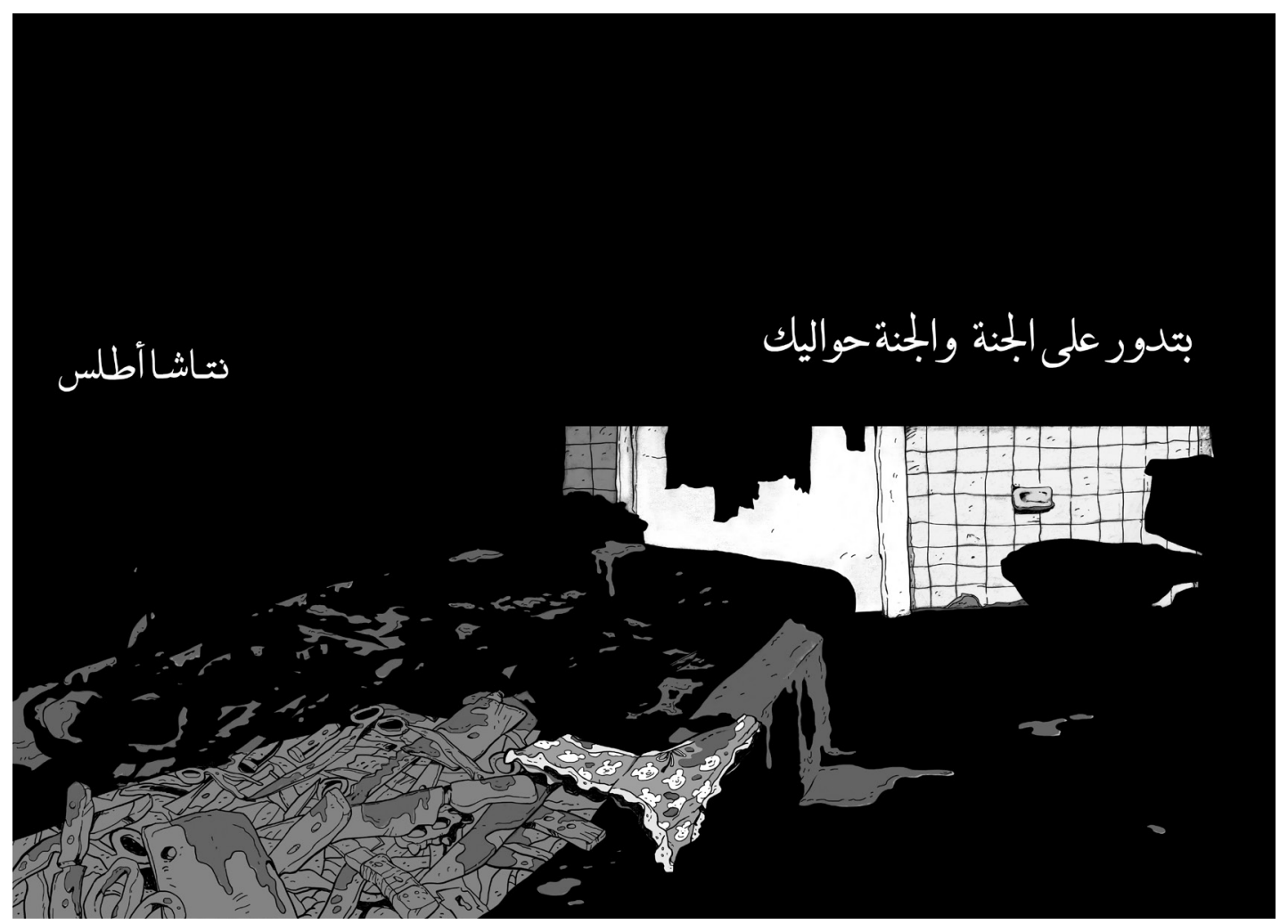

Fig. 1. "You are looking for Paradise while it surrounds you."

in the lyric. The graphic drawing plays a double function: its placement at the beginning of the novel anticipates traumatic forthcoming events. However, once retrieved by memory along the flow of events, it impacts retrospectively, especially towards the end. The opening graphic spread disrupts the code transmitted by Natasha Atlas's lyric, subverting the embedded meaning. The comic strips that follow are not set in consecutive order to create an alternative narrative; nor are they used as illustrations to the verbal texts. Conversely, they are as disconnected as the narrative text, at times supplementing the inarticulate in verbal language. The sparing snatches of dialogue in the subsequent strips are by an 
anonymous narrator, who even disappears from several sequences. Unlike classical comics that impose verbal on visual, the panels are generally self-sufficient, following what Groensteen propounds as a "poetics of reticence, ambiguity, and indeterminacy" (Groensteen 30).

The third verbal text following the graphic spread is an entry on Ibn 'Arūs, a medieval Upper Egyptian folk singer who turned from his life as a bandit to become a popular lyricist upon being jilted at the age of sixty by the young girl he loved. Ibn 'Arūs's lyrics are sung to this day at local fairs, or festive occasions in Upper Egyptian villages, by Shawqī Qenawī, a contemporary popular ballad singer, also mentioned in the entry on Ibn 'Arūs. The dates and national origins of Ibn 'Arūs are not definitive, as the narrator claims that information descending from ancestors and exchanged among contemporaries is liable to constant modification along the ages. The insertion of this entry pseudo-documenting the lives of both popular singers ji lted by their lover[s] function as commentary on the previous episode recounting Bassam Bahgat's - the protagonist narrator-disappointment as a result of his partner's betrayal; parallel situations in the novel intensify elements of indeterminacy and chance. The multimodal use of text, graphic design and popular music to map related private agonies among members of different social communities, enhances the sensation of "tsunami" morbidity on the local horizon. The second chapter extends this morbidity to the international horizon with texts and graphics critical of private and public Western modes of living. Enhancing sensations by the use of three modalities of media-verbal, visual and aural-simultaneously immerses the reader-viewer in the narrative experience.

Instead of a chronological plot-line, a series of episodes are spread along ten chapters, alternating verbal narrative, graphics or comic strips, as well as popular musical extracts. As verbal narrative visual comics and musical excerpts do not proceed in sequential order, they are mutually interruptive. Shifting visual, verbal and musical effects requires a pause, which disrupts narrative time and space. The verbal and visual are not attributed meaning in isolation, but relative to their occurrence in the text, and depend on the connections made in the process of reading. Multimodality or the use of multifarious media as referred earlier, coincides with the time-space "chronotopes," hence merging different historical temporalities and diverse locations. 


\section{Cityscape: Cairo}

The novel evolves through multiple temporality, and plurality of cultural narratives. Narratives from Cairo's past and present are related, to provide a background for ongoing events in the protagonists' private lives. In one of his interviews, Naji rightly opines that, "Cairo is a museum holding a plethora of historical buildings" (Ali 2014). Cairo residents daily commute along different phases of history marked by distinct architectural constructions and monuments, at times merging with shanty towns and popular districts. Past and present are active in the everyday life of ordinary Cairo inhabitants. Along with the presence of the historical past, the present has provided technological devices introducing parallel realities. Subsequently, events in the novel alternate inadvertently along the protagonists' private lived time and simulated reality. Correspondingly, Cairo's surviving monumental architectural constructions provide a cultural context of lived pasts, surrounding commuters, along with mediated pasts diffused through the media. Within the private domain, there are lived, recounted, dreamed and simulated times. By the same paradigm, Cairo is being lived as embodied space, and as virtual space. Inadvertent shifts in experiencing material and virtual realities in private and collective memory are one of the strategies used to destabilize progressivist ideologies. The shifts are prompted by environmental degeneration, social instability, abjection, and failed projects. Contingent cultural transformations make it difficult to mobilize a narrative of private or collective history on a single axis, which explains the plurality of cultural narratives on Cairo and of its inhabitants. These narratives are inserted in the action as comments on ongoing situations linking Cairo's past history to present actualities, in the same way protagonists reflect on their past lives in present sociopolitical situations.

Cairo has taken on several faces; the cityscape has undergone several changes under successive rulers. This is also configured in the changing roles of Egyptian women acting as traditional veiled women (Fig. 2) or unveiled modernized funky women (Fig. 3). These seeming binaries come along a series of graphic drawings. In a chapter titled, "The Animals of Cairo," a variety of male and female figures are featured combining grotesque human and animal features; they are named: "the Scoundrel," "Stray Dogs," "Dervishes," "cockroaches," among others. Verbal and visual text subverts these stereotypes by revealing their complexity, making it difficult to stigmatize them under one appellation. They configure an identity crisis incapable of coping with new demands from the altered social and economic changes. Both veiled ( $U L$ 90) and unveiled women ( $U L$ 92) fail to find a balance between developing their distinctiveness while still fitting in. Unlike former graphics combining visual and verbal in one panel, in this series, the verbal and visual are split into different panels to be read and viewed separately. 
Identity in crisis is a consequence of the persistent tradition/modernity conflict predominating the history of Cairo's architecture, cultural heritage, as well as social relations, and has been configured in different strips. This conflict has never been resolved either in Cairo's urban planning, or in the lives of its residents. The tradition/modernity conflict is further developed towards the end of the novel; a sequential panel features a televised story of a worker at a printing press, who abandons his wife after becoming emotionally attached to the printing machine he works on, and fantasizes about having a sexual relationship with it (UL 156-161). It is a humorous strip with multiple cultural specific connotations. Most of the panels are in a grotesque style, merging reality with fantasy; they convey a visual metaphor, alluding to inability in managing technological advancement to meet habitual living, or difficulties in reconciling rationality and affect. It may read as a tragicomic sequence, which adds to the ambiguity of the situation instead of clarifying it.
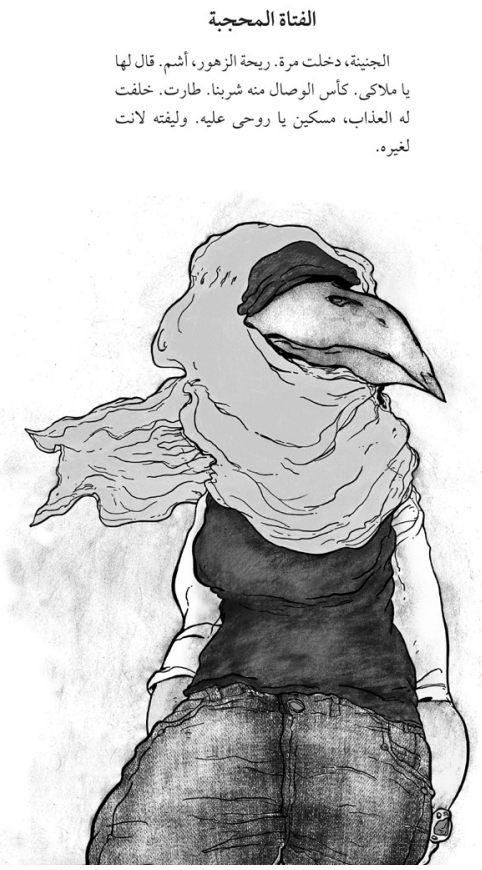

Fig. 2. Veiled woman.

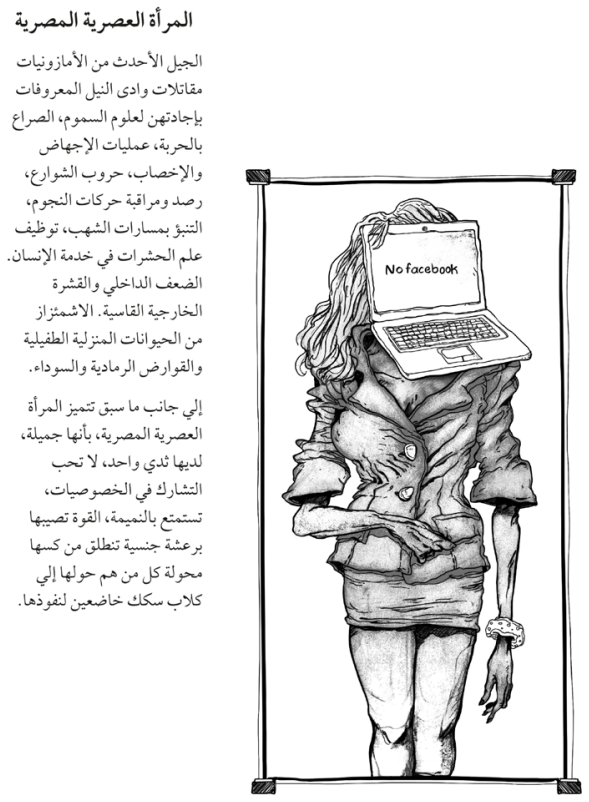

Fig. 3. Unveiled woman. 


\section{Catastrophe: appropriation and erasure}

The disconnected segments configure a lurking catastrophe which the reader/viewer apprehends as early as the opening chapters, especially that the opening episodes, graphics and musical extracts manifest the end of Cairo, the sad finale, before starting the narrative leading to this end. The reader is gradually led to sense a double risk lurking in the urban, ecological and sociopolitical environments. While the sociopolitical and environmental conditions of Cairo predict an inevitable disaster, later configured as a sand tsunami, its geopolitics is being manipulated by an economic strategy planned by the International Architects Association. This multinational Association is planning to sweep off Cairo City to have it replaced by a New Cairo. Cairo has always been designed by successive rulers to become the center of power. Moving the center of power from historic Cairo to a "New Cairo" by an international association of architects is of significance. The Association is a "global player," an "outsider" economic and a political actor and not the choice of local inhabitants. Its political activity beyond governmental control has increased the vulnerability of the system, which brings about Cairo's devastated condition. The latest previewed transformation by the Architectural Association claiming to have worked with reference to stored archived material lacks solid credentials, and their work turns out to be drawing a virtual map of New Cairo, a map that, "precedes the territory-precession of simulacra-that engenders the territory [...]" (Baudrillard, from "The Precession of Simulacra," 1981). Environmental degeneration and globalizing capitalism work concurrently. Towards the closure, global capitalism overlaps with crime increasing the threat, which is marked by a series of mishaps. Inadvertent events occur, such as the mysterious disappearance of Maud, one of the protagonists, the discovery of traces of a crime in the Association underground offices, and the frozen human flesh discovered by Bassam in Moonie Moon's refrigerator. The horrendous verbal images recuperate the prelude graphic spread featuring a tub floating with a bloody liquid in an abandoned bathroom. On one level, the closing events relate to the queries raised by the opening spread; on another level they raise additional questions as to the identity of the assassins and their intentions; together these reiterate the limitations of verbal and visual language to be fully articulate. The ambiguity of both verbal and visual languages, their inability to articulate a consistent plot-line configures Cairo's devastated condition as well as the chaotic condition of its inhabitants.

The speculative architectural project of New Cairo undertaken by the International Architects Association, created in response to a capitalist transnational scheme, intertwines with the fictional narrative (Plesch 145) recounting the interment of Cairo as a consequence of a devastating sand tsunami. The environmental disorder configures degenerating social relations, chaotic governmental 
policies and lack of governance. The verbal and architectural narratives critique centralized planning, cultural globalization, digitalization and monetization. This is rendered in the third sequential panel (Chapter 3), featuring Bahgat's first encounter with two members of the International Architects Association, who commission him to make a film on Cairo's architecture (UL 37-41). The different postures of standing outsider and seated insider, commissioner and commissioned, self-assuredness and incertitude are rendered by focusing on posture and facial expressions. While Bassam's posture conveys helplessness, his eyes reveal anxiety and negative affect (Fig. 4). Conversely, the Association members' blank eyes shaped in straight, circular and interwoven lines convey a tunnel vision (Fig. 5). This blank look creates a gap revealing the complexity of the relationship, whereby one party's inner emotions remains ambiguous; in that sense the images become performative as they immerse readers in the action.
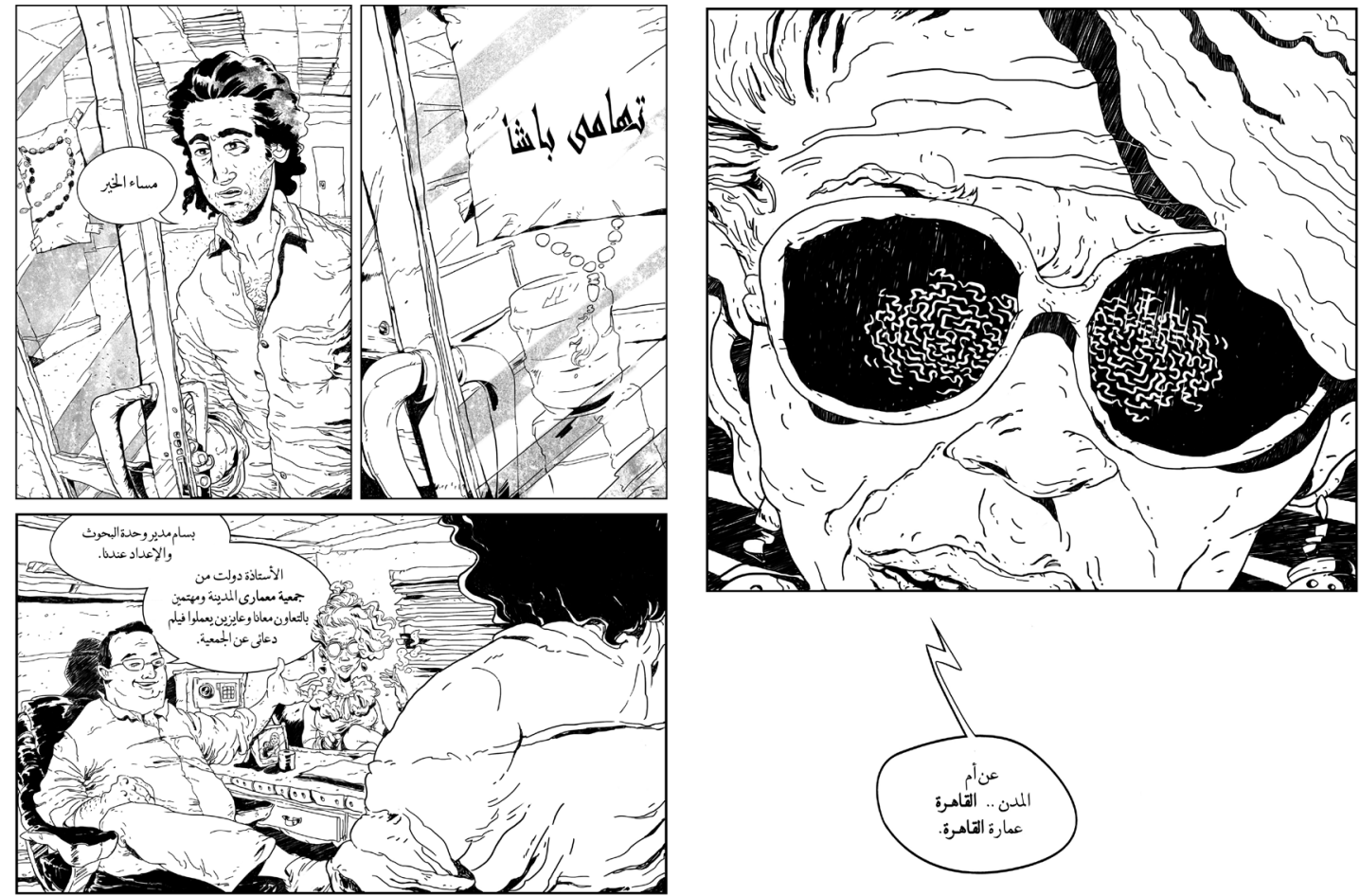

Fig. 4. Bassam Bahgat's first meeting with the Architects Association members.

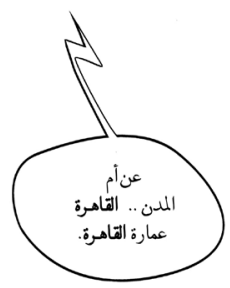

Fig. 5. Mrs. Dawlat, member of the Architects Association. 


\section{Delusions}

The presence of Ihab Hassan (1925-2015), the U.S.-American-Egyptian postmodernist critic, as a member of the International Architects Association is an implicit subversion of the postmodernism Hassan advocates. The construction of a New Cairo according to a simulated map designed by an international association, is totally divorced from Cairo's cultural history, and marks the failure of a postmodernist approach claiming its inclusiveness of cultural difference. Conversely, Bassam Bahgat, protagonist-narrator and his friends, contest the Association's rationalized globalizing scheme by leading the life of the flaneur. This mode of living also challenges the popular-turned-elitist postmodernist approach which had initially subverted rationalized modernization, but has later turned into theorization. The turn from live experience in an old Cairo throbbing with life, to the theorization and simulation of a "New Cairo" that replaces the old impedes the natural process of living. Subsequently, this explains Cairo's eventual devastation by an unprecedented sand tsunami.

However, the life of the flaneur does not promote the natural process of living either. Frustration with the flaneur's mode of living is rendered in the fourth comic strip (UL 71-78), configuring the impact of hasheesh on Bassam, the protagonist-narrator in the spatial graphic mode. Bassam is rendered in a condition of temporary amnesia that dissociates him from material reality, carries him afloat a paper boat sailing on a sea of dreams. The journey proceeds along downfalls and lifts, sinking in the sea, and flying in an air balloon, until he finally lands on a desolate location. The strip is made of a series of single images most of which are without captions, or with onomatopoeic sounds like the "crack" of the collapsing paper boat (Fig. 6). One does not view the panels in terms of before and after; the reader draws the meaning by reconstructing a simultaneous relationship connecting different images. Bassam's distraught condition materializes with the sudden appearance of an unknown person giving him back his lost purse. Instead of thanking him, Bassam resents the stranger's help, and responds with abusive language. Bassam subverts the superhero image; his life as flaneur indulges him in halfaccomplished pleasures. However, his indulgences cannot be classified as negative affect, as they are among the few choices offered in a censored environment.

The Bassam Bahgat-Ihab Hassan dis/alliance renders the paradoxical relationship dis/ connecting dissenting intellectuals from the masses. Hassan's presence is reminiscent of similar politico-cultural circumstances that have, with variation, previously taken place in Cairo's history. Ihab Hassan emigrated to the United States in 1946, when Cairo was metamorphosed by Khedive Ismail to become "part of Europe," engendering a cosmopolitan cultural environment. These were times when Egyptian Surrealists were at the peak of their performance; while closely connected to 


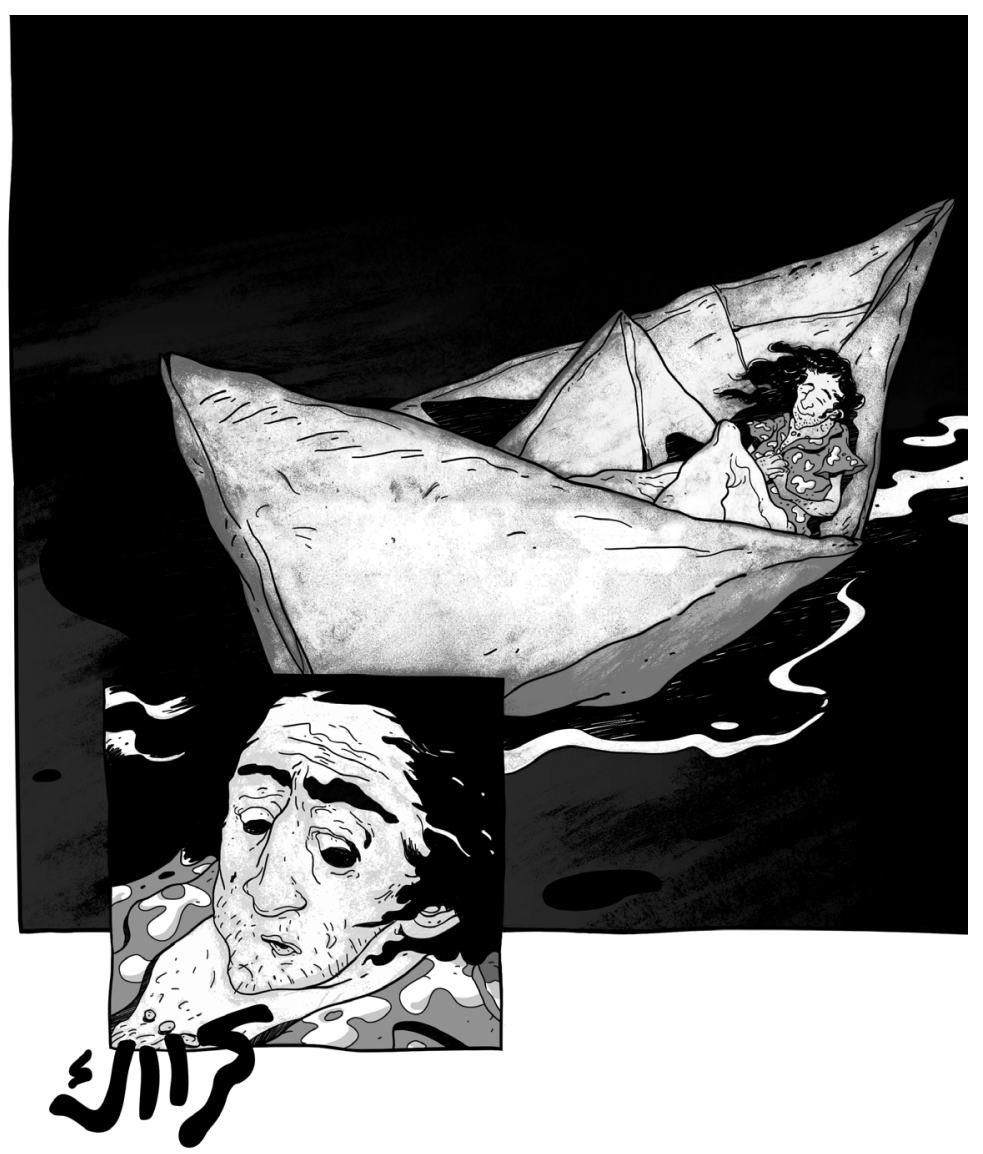

Fig. 6. Paper boat cracks. 
the International Surrealist movement, Egyptian Surrealists failed to achieve some of their aspirations in a cultural climate torn between modernists and conservatives (Kane 10-12). Similarly, Hassan, the postmodernist critic, while fully integrated into the American culture was totally divorced from the local culture to which he was related by birth. Most contemporary subversive youth movements as of the 1970s have appropriated the Egyptian Surrealists' modes of contesting the establishment. However, Naji and Zorkany push "degenerate" or "decadent" art a bit further. Naji's use of explicit language that almost verges on porno, his challenging description of sexual and gender relationships contest the growing social bigotry. Consequently, he has been unjustly persecuted and had to spend two years in jail in retribution (Koerber 2016). Ironically, this has increased the sales of the novel to over two million copies, a sign of wide reception, and the success of his strategy to debunk political repression and social inhibitions. The political establishment's unequal war against Naji's "decadent" fiction has contributed to the revival of political awareness, and augmented public resentment. Jacques Rancière defines "policing" not as "disciplining" of bodies" rather as a rule governing their appearing." Conversely, Rancière argues that, "politics [...] is antagonistic to policing." "Politics runs up against the police everywhere" (Rancière 29,30).

\section{Explications}

The subversion of formal genre conventions of the realistic novel, such as the absence of chronological temporality, of superheroes, of a conclusive message, as well as the lack of explicit language frustrates the habitual expectations of mainstream Arabic novel readers. In the same vein, Zorkany's subversion of formal comics conventions-the want of interpretive aids, the grotesque morbidity of his hybrid figures, unidentified mysterious location, heightened mood of existential estrangement in the fictional narrative-dramatically diverges his work from the commercial comics tradition. Furthermore, instead if using one style throughout, Zorkany experiments with a wide range of graphic styles. His comics production combines sequences of abstract drawings, as in the "You are looking for paradise," panel and drawings with figurative elements, which do not form a coherent narrative. Thierry Groensteen calls this graphic mode: "infranarrative comics" (Groensteen 10). In addition to the absence of a sequence linking the panels, occasionally, the panels and plot-line are not logically related. These visual strategies disorient the reader and make it difficult to infer a single interpretation, opening multiple semiotic possibilities. 
Although the final strip (Chapter 9) is sequential, it requires decoding the various layers of signification. It is a parody of horror comics, critical of Western assumed power based on technological advancement; simultaneously, the panels ironically convey the vulnerability of folk heroism. The strip configures an invasion by monstrous figures spurred on by Paprika and Madame Dawlat, both Architects Association members, along with the escape of the perpetrators who may belong to the Architects Association members. The monstrous unidentified figures in the strip are drawn in a "rhizomatic style" in contrast to Paprika (Fig. 7). Paprika is drawn in a dynamic line whereas the hooded figures appear as a sprouting rhizome. Bassam and Hassan are identified in the panels in the act of invoking forces of resistance; in a diagonal layout, Hassan uses a spray can to fend off the monster's assault, and is seen in the act of escaping with a bag. Conversely, Bassam is the only one to stand his stead, while he scares the assaulters by the use of explicit language-Hassan arms himself with technology, while Bassam relies on his innate forces (Fig. 9). The friction between two styles of drawing gives it a vital agility (UL 215-224).

The protagonists' figures are not represented in the same way all through; although they are recognizable they remain unrealistic. Drawings figuring Ihab Hassan have undergone an erasure (Fig. 8); Zorkany has previously caricatured "Ihab Hassan," the postmodernist icon, as an aristocratic snob (UL 116). In the final

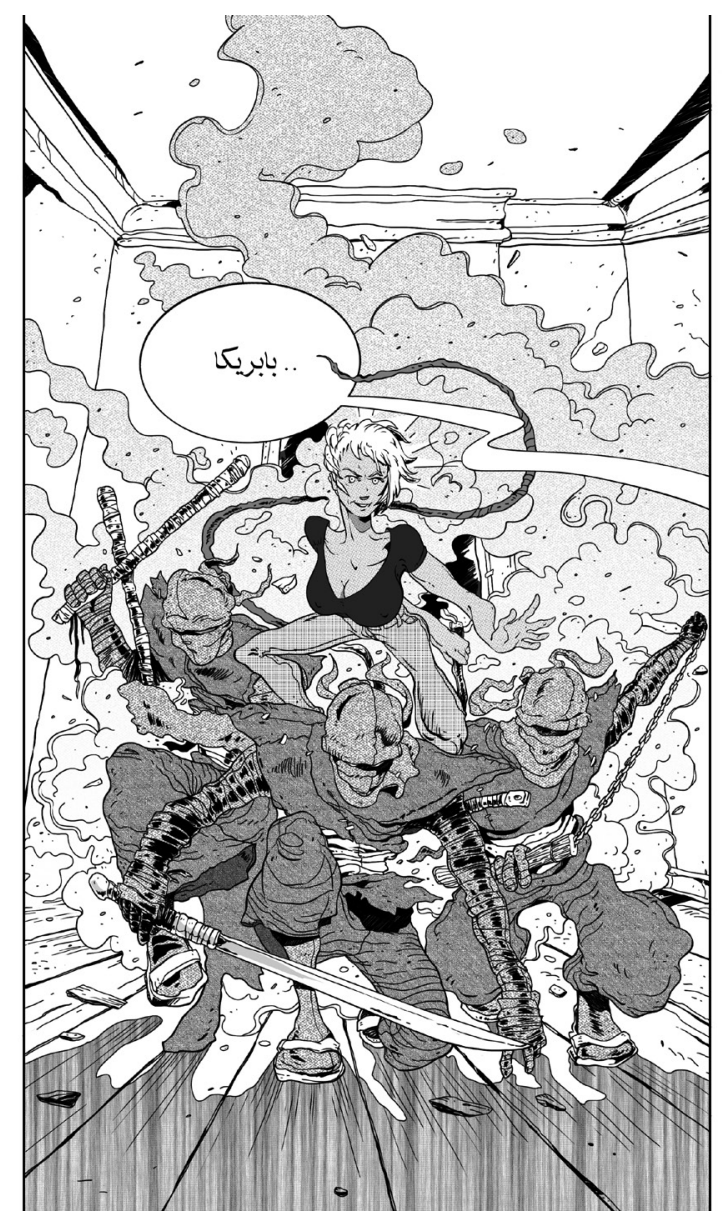

Fig. 7. Paprika 


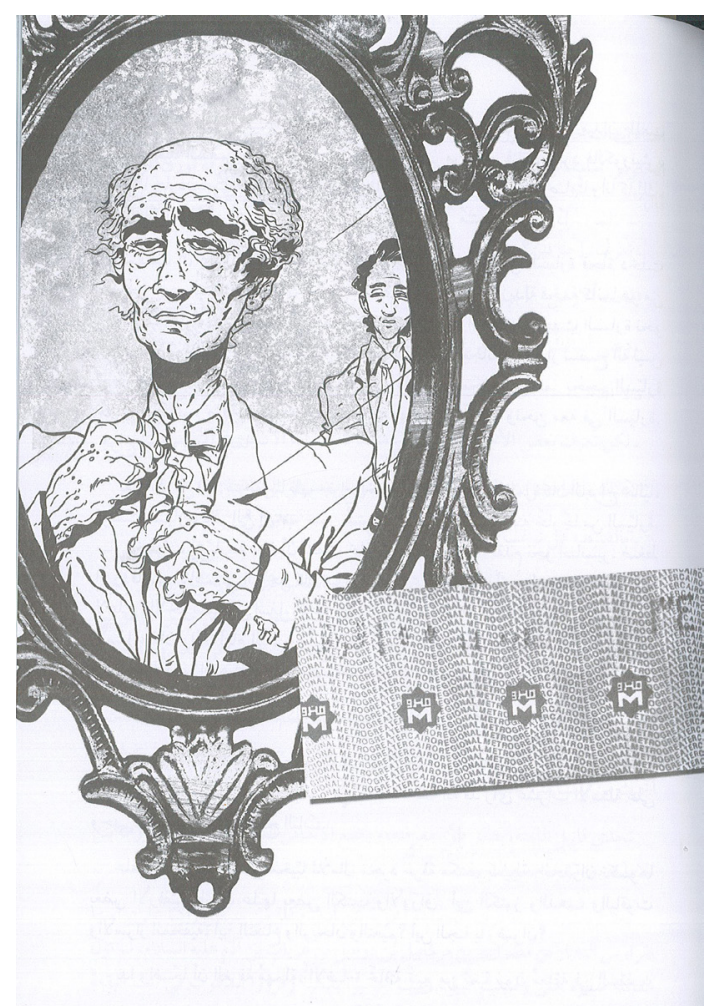

Fig. 8. Ihab Hassan caricatured portrait.
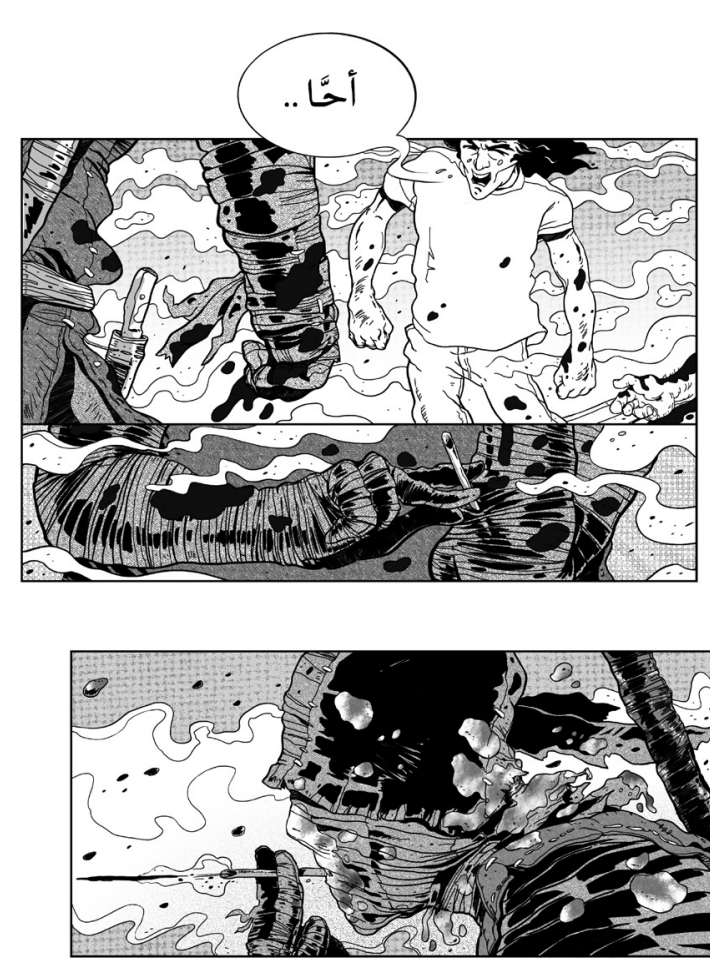

Fig. 9. Bassam Bahgat defying the invading forces.

strip ( UL 222), Hassan appears holding a spray can-lower left panel-to scare off the monstrous figures. The image comes with a caption that translates into English as, "God has deemed this to be fair" ( Fig. 10). The word "fair" in Arabic translates as "hassan," the surname of the American critic, posturing as one of the protagonists in the novel. This caption, which is appropriated from a sacred text, may serve as a commentary on the whole situation, expressing satisfaction with the break in the Association's bond, and considering it as a blessed supernatural intervention. 
The final comics strip disrupts the reader's expectations of knowing the victor in the fantastic/real battle featured, and the strip sequence ends with no resolution. An unidentified monstrous figure sits blowing arrows; his crane reveals a conspiratorial scheme aiming at the destruction of Cairo's architectural constructions (Fig. 9). The sequence configures the verbal narrative line that has assumedly occurred before the events of the novel begins. It also relates to an earlier entry about Hanafĩ Ahmed Hassan, another well-known singer of popular lyrics. His most reputed ballad is Shafíqa and Metwali an old popular ballad about the shame killing of Shafiqa, upon the denouncement of her secret love bond with Metwalī. This entry preludes the series of killings taking place among the Association's members towards the close of the novel. It enhances the element of betrayal, denouncement, and distress. Distress is sensed on the local and international levels.

The prelude included the morbid graphic spread, ironically captioned "You're looking for paradise while it surrounds you"; a chapter titled "Music's Cemetery," recounting betrayals and disappointments; the finale's prelude-an episode also titled, "Music's Cemetery," alluding to the decline of harmonious living. In the finale is the announced death of music acts as a commentary on Paprika's schemes, a leading member of the Architects Association, who along with her accomplices are proceeding with their atrocious plan-the mutilation of Cairo's architectural and
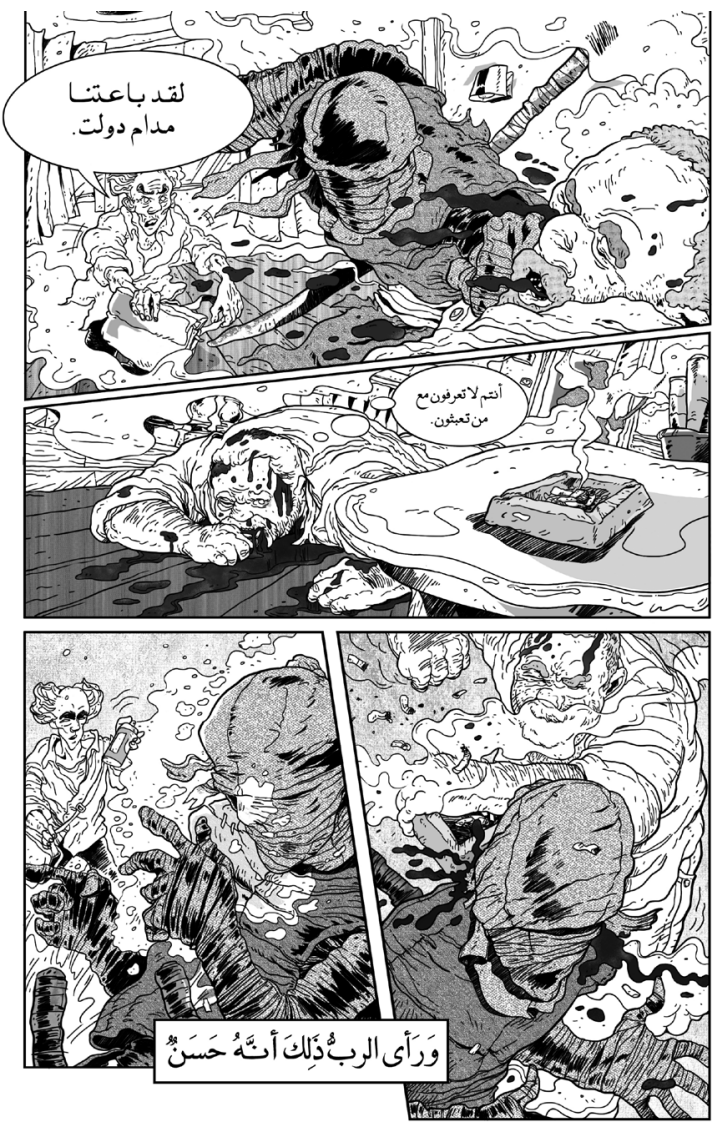

Fig. 10. Ihab Hassan scaring away the invading forces with a spray can. 
cultural history. The chapter evokes a dolorous tempo of a musical piece, and sounds the dissonance of the chaotic events. This noise, the concoction of a medley of fraudulent plans and horrendous events is allied to the constant denouncement of listeners to old musical pieces as inhibited individuals devoid of the joy of life. This sad prelude commences a series of upcoming disasters, along with a grotesque sequential panel.

The episodes at the closure render mysterious events, marking the sudden disappearance of protagonists, either by departure, death, escape, or floating away in a hot air balloon. The mystery is intensified by the narrator-protagonist's self-reflexive awareness that he may merely be an idea, an image, a simulacrum the way Cairo City has always been (UL 196, 198). In line with this indeterminacy, the recognizable figures in Zorkany's drawings are never repeated in the same style; they acquire new attributes with the changing situations, never becoming attached to an archetype, or reduced to a referent. By analogy, the mysteries are not resolved by magical resolutions; unresolvedness is a strategy inducing the reader to become aware of the constructedness of all narratives related to the self, Cairo, or a single global cultural history. By subverting readers' expectations the verbal visual narrative affirms its dissidence, its opposition to ideologically charged generic and formal conventions established by mainstream literature or art. The use of spatio-temporal strategies offers empowering alternatives that are more engaging to local and global readers alike by opening up spaces for different points of view, engaging them in identifying conflicting perspectives.

It is no wonder that novels that are graphic in part or whole are finding better chances to be translated despite their limited number. Jaqueline Brendt has postulated in her introduction to Comics Worlds and the World of Comics: Towards Scholarship on a Global Scale (2010) that bande dessinée, manga and manhau, historietas, beeldverhalen and fanzines "share the inclination toward escaping the "national"' (Brendt 5). Using Life crosses borders by appropriating classical global and local multimodal sources across historical periods. It shifts inadvertently between Lucretius, classical and popular Arabic sources, global and local singers' lyrics, high stylized classical Arabic language, everyday Egyptian dialects, and obscene language; all speech registers used are mutually unintelligible. Likewise, the graphic images toggle between various design layouts, inspired by various artistic styles unlimitedly.

\section{Conclusion}

Using Life transgresses boundaries among visual, verbal, and aural-mainstream and popular, and tends to be transcultural. Both Naji and Zorkany declined claims for national particularities, and this 
is evident in their joint work. Naji has broken with the classical Arabic tradition and mainstream culture that claim objectivity through "the signifying units of a language [...] that are impersonal" (Bakhtin 1986, 95). Their creative work is in Bakhtinian terms a heteroglossia of languages, acknowledging a multifarious community of addressees, along with a changing relationship between speaker and addressee(s) that can never come to a standstill. The use of different speech registers is a technique of engagement, immersing the readers from disparate communities by providing them with space to become "actively responsive" (Bakhtin 1986, 95), by allowing "various social 'languages' [...] to interact with one another" (Bakhtin 1992, 282).

Correspondingly, Zorkany broke away with classical art training at the Faculty of Fine Arts, in Cairo, as well as with comics styles used by emerging Egyptian comics artists' inspired by American and European comics. His drawings are aimed at trained and untrained viewers belonging to varied social communities. His visual language is in different styles since they are not reaching out for a fixed code, rather engaging viewers outside the framework of social conventions in order to establish a familiarity reaching their sensations. Familiar speech and unofficial art styles can "play a positive role in destroying the official medieval picture of the world," Bakhtin postulates, giving examples from literary history (Bakhtin 1986, 97). Naji and Zorkany both aimed at a new strategy for engagement by opening fiction and graphics to "layers of language that had previously been under speech constraint" (Bakhtin 1986, 97). This is made clear in an interview Naji had with Mona Kareem, where he expressed his belief that the traditional novel is "nearing extinction [...] and images continue to take over the human consciousness, leaving us with a new language" (Kareem 2014 npn).

Along the same lines, Groensteen postulates that towards the end of the twentieth century comics are "becoming literature," or what we call the graphic novel. He quotes Alain Berland, that a comics author should engage "in multiple hybridization with other artistic disciplines" (Groensten 175). Groensteen does not see that this would lead to an "artist's book." Naji's and Zorkany's joint book shows that the need to hybridize is an urge to run counter to the mainstream. Their multimodal text belongs to a worldwide emerging youth subculture seeking uninhibited means of communication to engage addressees by touching on their sensations, while being indifferent to cultural legitimacy. Lambeens and Pint argue that an: "intelligent combination of code and sensation in fact reveals the distinctive possibilities of the comic genre in comparison to other more established genres like film, literature or painting" (Lambeens and Pint 255). Comics have opened new possibilities for Egyptian writers and artists, and the word "komix" has become a loanword appropriated in Egyptian dialect. Subsequently, komix calls for a cross-cultural method of research that resists compartmentalization within one critical scholarship. 


\section{Works Cited}

ALI, Iman. Interviewing Ahmed Naji, "Cairo as a Huge Museum.” Al Hayat newspaper. Beirut. 16 November 2015. http://www.alhayat.com/m/story/12182468

BAKHTIN, Mikhail. The Dialogic Imagination. Austin: University of Texas Press, 1981; 1992).

Rabelais and his World. Bloomington: Indiana University Press, 1984a.

Speech Genres \& Other Late Essays. Translated by Vern W. Mcgee. Ed. Caryl Emerson and Michael Holquist. Austin: Texas University Press, 1981; 1986; 10th edition 2006.

BAUDRILlARD, Jean. Simulacres et simulation. Paris: Gallilée, 1981:9. Simulacra and Simulation. Translated from French by Sheila F. Glaser. University of Michigan Press, 1994. https://monoskop.org/images/4/4b/Baudrillard_Jean_Simulacres_et_simulation_1981.pdf

BRENDT, Jaqueline, (ed.). "Introduction: attempts at cross-cultural comic studies." Comic Worlds and the World of Comics: Towards Scholarship on a Global Scale. (Series, Global Manga Studies, vol. 1). International Manga Research Center, Kyoto Seika University, 2010.

The Coptic Museum, Cairo.

http://www.coptic-cairo.com/museum/selection/manuscript/manuscript.html

DAMLUJI, Nadim. “The comic Book Heroes of Egypt.” Qulture. Doha. Accessed 09/11/2016. http://www.qulture.com/arts/comic-book-heroes-egypt

El SHAFEE, Magdy. Metro. Cairo: Mohammed El Sharqawy, 2008. Translated by Chip Rosetti. New York: Metropolitan Books, 2012.

ELleSTROM, Lars (ed.). Media Borders, Multimodality and Intermediality. Hampshire: Macmillan, 2010. Palgrave, 10.1057/9780230275201

FATHI, Ibrahīm. Kumīdya al-ㅂukum al-Shumūliyy . [The comedy of totalitarian regimes.] Cairo: General Egyptian Book Organization, 1991.

GROENSTEEN, Thierry. Comics and Narration. Translated by Ann Miller. Mississippi: University of Mississippi Press, 2013.

KANE, Patrick. "Art Education and the Emergence of Radical Art Movements in Egypt: The Surrealists and the Contemporary Arts Group, 1938-1951." Journal of Aesthetic Education, 44: 4 (Winter) 2010: 95-119.

KAREEM, Mona. "Warning: this may injure your modesty." Pandaemonium. 2014. Accessed May 19, 2016. https://kenanmalik.wordpress.com/2016/05/19/warning-this-may-injure-your-modesty/

KOERBER, Benjamin. "Using Life: Instructions for Play.” The New Inquiry. May 16, 2016. http://thenewinquiry.com/essays/using-life-instructions-for-play/

KRESS, Gunther. "Multimodalities." Multiliteracies: Literacy Learning and the Design of Social Futures. Eds. Bill Cope and Mary Kalantzis. London: Routledge 2000, 182-200.

http://www.users.miamioh.edu/simmonwm/kress_multimodalities.pdf

LAMBEENS, Tom and Kris PINT. "The Interaction of Text and Image in Modern Comics." Texts, Transmissions, Receptions: Modern Approaches to Narratives. Eds. André Lardinois, Sophie Levie, Hans Hoeken and Christoph Lüthy. Readout Studies in Humanities, Vol. 1. chapter 14. Leiden, Netherlands: Brill, $2014 .$. Accessed 09/12/2016.

http://booksandjournals.brillonline.com/content/books/9789004270848 
LEFÉVRE, Pascal. "Recovering Sensuality in Comic Theory." International Journal of Comic Art. 1, (1999): 140-149.

LUCRETIUS CARUS, Titus. The Nature of Things: De Rerum Natura. Trans. from Latin by William Ellery Leonard .July 31, 2008 [Gutenberg EBook \# 785]. http://www.gutenberg.org/ebooks/785

MARGOT Afaf Lutfi Al-Sayyid. "The Cartoon in Egypt.” Comparative Studies in Society and History. 13: 1 (Jan. 1971): 2-15. http://www.jstor.org/stable/178195. Accessed: 17-01-2016 17:14 UTC.

NADI, Ahmad, Ganzeer, and Donia MAHER. The Apartment at Bab El Louk, Cairo: Dār Merit: 2000. Trans. from Arabic by Elisabeth Jacquette. Excerpts published in Words without Borders. VIII (February 2015):

http://www.wordswithoutborders.org/graphic-lit/the-apartment-in-bab-el-louk

NAJI Ahmed, and Ayman EL ZORKANY. Istikhdām al-hayāt. Cairo , Beirut \& Tunis: Dar al-tanwīr, 2014. In English, Using Life. Trans. from Arabic by Benjamin Koerber. Austin: Texas University Press, forthcoming 2017. Awarded PEN/Barbey Freedom to Write Award, New York, 2016.

NELSON, Mark Evan, Glynda HULL and Jeeva ROCHE-SMITH. "Challenges of Multimedia Self-Presentation: Taking, and Mistaking, the Show on the Road." Written Communication. 25: 4 (October 2008); 415440.. DOI: $10.1177 / 0741088308322552$. $\mathrm{http} / / /$ wcx.sagepub.com/content/25/4/415

PINT, Kris. "The Avatar as a Methodological Tool for the Embodied Exploration of Virtual Environments." CLCWeb: Comparative Literature and Culture 14:3 (2012): <http://dx.doi.org/10.7771/1481-4374.2037. Accessed 09/11/2016.

PLESCH, Veronique. "Literary Spaces." In Once Upon a Place: Architecture \& Fiction. Ed. Pedro Gadanho and Susana Oliveira. Lisbon: Caleidoscópio (2013): 145-47.

RANCIÈRE, Jacques. Disagreement: Politics and Philosophy. Mineapolis: University of Minnesota Press, 1999. 


\section{List OF ILLUSTRATIONS}

Fig. 1. "You are looking for Paradise while it surrounds you."

Fig. 2. Veiled woman.

Fig. 3. Unveiled woman.

Fig. 4. Bassam Bahgat's first meeting with the Architects Association members.

Fig. 5. Mrs. Dawlat, member of the Architects Association.

Fig. 6. Paper boat cracks.

Fig. 7. Paprika

Fig. 8. Ihab Hassan caricatured portrait.

Fig. 9. Bassam Bahgat defying the invading forces.

Fig. 10. Ihab Hassan scaring away the invading forces with a spray can. 